\title{
Wound healing of diabetic rats treated with Moringa oleifera extract ${ }^{1}$
}

Ítalo Medeiros Azevedo', Irami Araújo-Filho", Marianny Maiara Antas Teixeira"l, Marília Daniela Ferreira de Carvalho Moreira'v ${ }^{\mathrm{N}}$, Aldo Cunha Medeiros ${ }^{v}$

'Fellow PhD degree, Postgraduate Program in Health Sciences, Universidade Federal do Rio Grande do Norte (UFRN), Natal-RN, Brazil. Acquisition and interpretation of data, technical procedures, manuscript preparation.

"PhD, Assistant Professor, Department of Surgery, UFRN, Natal-RN, Brazil. Technical procedures, manuscript preparation. "'Graduate student, UFRN, Natal-RN, Brazil. Technical procedures, manuscript preparation.

IVPhD, Hospital Universitário Onofre Lopes, UFRN, Natal-RN, Brazil. Technical procedures, manuscript preparation.

${ }^{v}$ Full Professor, Chairman, Nucleus of Experimental Surgery, UFRN, Natal-RN, Brazil. Conception, design, intellectual and scientific content of the study; critical revision.

\section{Abstract}

Purpose: To evaluate if Moringa oleifera leaf aqueous extract (ME) influences the healing of skin wounds of diabetic rats.

Methods: Wistar rats were used (6 rats/group). Group 1 received normal saline (NS) v.o. Group 2 received moringa extract (100mg/kg v.o) for 3 weeks. Groups 3 and 4: Streptozotocin (STZ) induced diabetes. Group 3 received NS; Group 4 received aqueous ME $(100 \mathrm{mg} / \mathrm{kg})$ v.o.The wounds of groups 1 and 3 rats were topically treated with NS; wounds of groups 2 and 4 treated with $200 \mu \mathrm{L}$ of $10 \%$ ME. After anesthesia, all rats had skin square excision wounds $1.5 \mathrm{~cm}^{2}$. Wound percent contractions were measured. On 10th day, blood glucose and serum cytokines were measured. Histometry of wounds was studied using ImagePro6.0 software. Results: Glycemia was significantly reduced in ME treated rats. These rats had higher percent contraction of the wounds on $2^{\text {nd }}, 5^{\text {th }}$ and $10^{\text {th }}$ days, then controls $(p<0.05)$. Diabetic rats treated with NS had TNF- $\alpha, \mathrm{IL}-1 \beta$ and IL- 6 expression higher than in rats receiving ME. The histopathological score of ME treated diabetic rats (198 \pm 13.7$)$ was significantly higher than treatment with NS $(145 \pm 10.5)$.

Conclusion: ME extract positively influenced healing of wounds in diabetic rats after systemic and topical treatment.

Key words: Wound Healing. Diabetes Complications. Moringa oleifera. Rats. 


\section{Introduction}

Wound healing is a complex and dynamic process involving biochemical, immunological and physiological processes in order to guarantee tissue repair ${ }^{1}$. Wound healing consists of an orderly progression of events. Some of them occur immediately after injury, others after a few days and some later in order to re-establish the integrity of the damaged tissue. Inflammatory, proliferation and remodeling phases happen. Alterations in any of these phases can lead to healing delay or even the inability for wound healing ${ }^{2}$. The inflammation stage begins immediately after injury, first with vasoconstriction that favors homeostasis and after, vasodilation releases inflammation mediators. In the proliferative phase we can see the granulation tissue formed mainly by fibroblasts, collagen, fibrin and the angiogenesis process. In the remodeling of granulation tissue, we see the predominance of type I collagen compared with type III collagen, and the reduction of water, proteins, proteoglycans, glycoproteins and other components. Collagen synthesis and maturation is essential for wound healing and may be affected by iron, $\mathrm{O}_{2}$, vitamin $\mathrm{C}$ and alpha-ketoglutarate ${ }^{3}$.

WHO estimated that 422 million adults were living with diabetes in 2014, compared to 108 million in 1980, rising from 4.7 to $8.5 \%$ in the adult population ${ }^{4}$. This world Organization projects that diabetes will be the seventh leading cause of death in $2030^{4}$. Diabetes mellitus is a disease with multimode complications and our society wishes to have an urgent solution for this disease. Though a number of studies in nanotechnology, new drugs have been carried out, and for the discovery of medicine from plant origin. These studies need a large improvement ${ }^{5}$.

Various types of plants have been used for several centuries worldwide not only as dietary supplements but also as traditional treatment regimens for many diseases. So far, a large number of traditionally claimed plant medicine has been tested for diabetes and some of them have showed a promising therapeutic potential. Among these plants, a rapidly growing perennial tree, Moringa oleifera (Moringaceae family) is widely distributed in Asia, America, and Africa.

In the system of traditional Indian medicine, Moringa oleifera is considered to carry hypoglycemic activity. It is an important source of vitamin C, iron, potassium, lipids, proteins, beta-carotene, and other nutrients ${ }^{6}$. The major phytochemicals present in the Moringa oleifera leaf are niazinine, niazimycin, b-sitosterol, glucomoringine, n-benzyl thiocarbamates, kaempferol, other natural antioxidant molecules including vitamins, minerals and carotenoids ${ }^{7}$. Some studies have been reported on the antidiabetic potential of Moringa oleifera ${ }^{7,8}$. The aqueous extract is preferred for therapeutic purposes. Moringa oleifera has been investigated for its wound healing ${ }^{9}$, antiinflammatory, antimicrobial ${ }^{10}$, and antidiabetic ${ }^{11}$ properties. The aim of this protocol is to examine if Moringa oleifera leaf aqueous extract is able to influence the healing of skin wounds of diabetic rats.

\section{Methods}

\section{Plant and aqueous extract preparation}

Leaves of Moringa oleifera were purchased from California Gold Nutrition. The plant material was processed into fine powder. The powder (200 g) was extracted through maceration with continuous stirring for $24 \mathrm{~h}$ using distilled water. The extract was filtered and lyophilized. The obtained dried aqueous extract was stored at $4^{\circ} \mathrm{C}$ until use. 


\section{Animals}

The protocol employed is in accordance with the principles of law 11.974/08 (CONCEA) and was approved by the Institutional Ethics Committee on Animal Use (Protocol No. 05/2018).

Wistar adult rats (Rattus norvegicus) weighing $280 \pm 23 \mathrm{~g}$ acquired from the Health Sciences Center Vivarium of Universidade Federal do Grande do Norte, were used. During maintenance period (at least 7 days before the beginning of study) all animals were housed in polypropilene cages, under a climate-controlled environment $\left(22^{\circ} \mathrm{C}\right)$, a $12-\mathrm{h}$ light:12-h dark cycle and ad libitum access to water and convectional standard palletized laboratory ration (Prevence ${ }^{\circ}$ ).

\section{Streptozotocin-induced diabetes}

A single dose of $45 \mathrm{mg} / \mathrm{kg}$ body weight of freshly prepared streptozotocin (STZ, S0130, Sigma Aldrich) in $0.1 \mathrm{~mol} / \mathrm{L}$ citrate buffer $(\mathrm{pH}$ 4.5) was injected intraperitonealy for the induction of diabetes in overnight fasted rats. After two days of STZ treatment, diabetes mellitus was developed in the test groups, which was confirmed by assessing fasting blood glucose from the tail vein of overnight fasted rats. The dosage was performed using AccuCheck, Roche Diagnostics, Germany. Rats with blood glucose of $250 \mathrm{mg} / \mathrm{dL}$ or higher were considered to be diabetic and were included in the study.

\section{Experimental design}

Rats were allocated into four groups (6 per group). Group 1 received normal saline (NS) v.o. and served as control; Group 2 received aqueous moringa extract $(100 \mathrm{mg} /$ kg) v.o. (gavage) and served as sham control. Groups 3 and 4 were treated with STZ to induce diabetes. In addition to STZ treatment, Group 3 received NS and served as toxic control; Group 4 received aqueous moringa extract (100 mg/kg) v.o. (gavage) and served as test group. The wounds of groups 1 and 3 rats were topically treated with NS; 2 and 4 groups rats were topically treated with $200 \mu \mathrm{L}$ of $10 \%$ aqueous moringa extract. The topical and oral treatments started in the same day in groups 2 and 4 .

After anesthesia by ketamine $80 \mathrm{mg} / \mathrm{kg}$ and xylazine $7 \mathrm{mg} / \mathrm{kg}$ i.p., the back of animals were shaved and antisepsis was performed with $70 \%$ alcohol. Skin square excision wounds sized $1.5 \mathrm{~cm}^{2}$ were made in all rats. The wounds were analyzed at $2^{\text {th }}, 5^{\text {th }}$ and $10^{\text {th }}$ days and wound area contractions were measured by using a picture photographed $15 \mathrm{~cm}$ distant from the animal dorsal skin (Sony CyberShot HD camera, Japan). Percentage reduction of initial wound area was calculated, by using the ImagePro Plus 6.0 software.

On the 10th day, blood glucose was measured again, and blood was collected by cardiac puncture for cytokines dosing. Blood was centrifuged and the serum separated for TNF- $\alpha$, IL-1 $\beta$, IL- 6 dosing by the ELISA technique using PeproTec kits, USA, according to manufacturer's instructions. Then, the rats were euthanized with overdose of thiopental (100 mg/kg i.p.).

\section{Histopathological study}

Harvested skin wounds specimens from treated and untreated rats. The fresh tissue was sectioned into $5 \mathrm{~mm}$ thickness fragments and washed in running water allowing rapid and uniform action of the fixative solutions. Samples were fixed in $10 \%$ buffered formaldehyde for a maximum period of 48 hours, then processed for 18 hours in an automated tissue processor using Leica TP 1020 equipment. Prior to paraffin inclusion, the processed fragments were cut 
with punch-type equipment, in the gauge of 06 $\mathrm{mm}$, for standardization of samples.

The histological sections were cut with Leica RM 2125 RTS microtome, at a thickness of 4 microns, in previously silanized slides. Fixed samples were stained by hematoxylin /eosin and Masson's trichrome histochemical technique, for morphological analysis in microscope (Olympus BX50, Japan). Quantitative evaluation of collagen fibers, fibroblasts, vascular neoformation and macrophages was performed using the ImagePro Plus 6.0 software (Rockville, MD, USA). Five microscopic fields of 5 slides per group were analyzed, and the mean of the scores obtained for each group was calculated. The results were expressed as mean \pm standard deviation.

\section{Statistical analysis}

A comparison was made between groups and the results were analyzed statistically using multi-way ANOVA. The Kruskal Wallis test and Dunn's test were also used to compare the differences between treated groups and controls. The differences were considered significant at $p<0.05$.

\section{- Results}

\section{Evolution of glycemia with treatments}

In Table 1 it can be observed that in the control group and in diabetes group treated with normal saline, there was no significant difference between the levels of glycemia on the second day of dosing and on the 10th day. $(p>0.05)$. When the animals were treated with moringa extract (ME), there was a significant reduction in glycemia, comparing the 2 nd day with the 10th day of treatment in the $\mathrm{C} / \mathrm{ME}$ and $\mathrm{DIAB} / \mathrm{ME}$ groups $(\mathrm{p}<0.05)$.
Table 1 - Measurement of blood glucose in the $2^{\text {nd }}$ day and $10^{\text {th }}$ day after STZ injection in rats of the study groups.

\begin{tabular}{lll} 
& $\begin{array}{l}\mathbf{2}^{\text {nd }} \text { DAY } \\
\text { Glycemia } \\
(\mathbf{m g} / \mathbf{d L})\end{array}$ & $\begin{array}{l}\mathbf{1 0}^{\text {th }} \text { DAY } \\
\text { Glycemia } \\
(\mathbf{m g} / \mathbf{d L})\end{array}$ \\
\hline C/NS & $145.1 \pm 12.3^{\text {a }}$ & $152.3 \pm 10.8^{\mathrm{b}}$ \\
C/ME & $158.4 \pm 11.8^{\text {a }}$ & $123.6 \pm 10.4^{\text {a }}$ \\
DIAB/NS & $287.6 \pm 18.4^{\text {b }}$ & $268.3 \pm 16.7^{\text {a }}$ \\
DIAB/ME & $302.5 \pm 20.2^{\text {a }}$ & $207.9 \pm 14.2^{\text {a }}$ \\
\hline
\end{tabular}

C, control; ME, Moringa extract; DIAB, diabetes; NS, normal saline. Measures followed of the same letter in the same line differ significantly ( $p<0.05$, Tukey test).

\section{Percent reduction of wound area}

In groups treated with Moringa oleifera aqueous extract (both control group and diabetic group) we observed a higher percent contraction of the wounds on $2^{\text {nd }}, 5^{\text {th }}$ and $10^{\text {th }}$ days, when compared with the wounds treated with normal saline (Table 2). The differences were significant $(p<0.05)$.

Table 2 - Percent of contractions of wound size in the days $2^{\text {nd }}, 5^{\text {th }}$ and $10^{\text {th }}$ after treatment with Moringa extract in rats with diabetes and controls.

\begin{tabular}{llll}
\hline Groups & $\mathbf{2}^{\text {nd }}$ Day & $\mathbf{5}^{\text {th }}$ Day & $\mathbf{1 0}^{\text {th }}$ Day \\
\hline C/NS & $1 \%^{\mathrm{a}, \mathrm{b}}$ & $15 \%^{\mathrm{a}, \mathrm{b}}$ & $61 \%^{\mathrm{a}}$ \\
C/ME & $15 \%^{\mathrm{a}}$ & $32 \%^{\mathrm{a}}$ & $92 \%^{-}$ \\
DIAB/NS & $0,8 \%$ & $25 \%^{\circ}$ & $64 \%^{\mathrm{b}}$ \\
DIAB/ME & $12 \%^{\mathrm{b}}$ & $28 \%^{\mathrm{b}}$ & $88 \%^{\mathrm{a}, \mathrm{b}}$ \\
\hline
\end{tabular}

C, control; ME, Moringa extract; DIAB, Diabetes; NS, normal saline. Measures followed of the same letter in the same column differ significantly $(p<0.05)$.

\section{Serum cytokine dosage}

The expression of TNF- $\alpha$, IL- 16 and IL- 6 occurred in a significantly lower level in the serum of control rats treated with moringa 
aqueous extract than in controls treated with saline. Diabetic rats treated with normal saline had TNF- $\alpha$, IL-16 and IL- 6 serum expression higher than in those receiving moringa aqueous extract v.o. in each group. These data are summarized in Table 3.

Table 3 - Values of TNF, IL-1 $\beta$ e IL-6 in treated and untreated rats with Moringa extract. Control and diabetic animals were studied.

\begin{tabular}{llll}
\hline Groups & TNF $\alpha(\mathrm{pg} / \mathrm{ml})$ & $\mathrm{IL}-1 \beta(\mathrm{pg} / \mathrm{ml})$ & IL-6 $(\mathrm{pg} / \mathrm{ml})$ \\
\hline C/NS & $274.5 \pm 26^{\mathrm{a}}$ & $77.2 \pm 16^{\mathrm{a}}$ & $140.5 \pm 23^{\mathrm{a}}$ \\
C/ME & $136.4 \pm 18^{\mathrm{a}}$ & $43.3 \pm 11^{\mathrm{a}}$ & $108.2 \pm 12^{\mathrm{a}}$ \\
DIAB/NS & $312.3 \pm 21^{\mathrm{a}}$ & $98.3 \pm 14$ & $83.6 \pm 13$ \\
DIAB/ME & $215.7 \pm 24^{\mathrm{a}}$ & $67.3 \pm 12^{\mathrm{a}}$ & $64.2 \pm 9^{\mathrm{a}}$ \\
\hline
\end{tabular}

C, control; ME, Moringa extract; DIAB, Diabetis; NS, normal saline. Measures followed of the same letter in the same column differ significantly ( $p<0.05$, Tukey test).

\section{Histopathology}

After quantitative evaluation of collagen fibers, fibroblasts, vascular neoformation and macrophages carried out using the ImagePro Plus 6.0 software, we observed that the score of control group rats treated with moringa extract $(274 \pm 11.8)$ was higher than the score of control group rats treated with normal saline (186 \pm 8.3$)$. The same occurred in diabetic animals. The score of the animals treated with moringa extract $(198 \pm 13.7)$ was higher than in the diabetic rats treated with normal saline $(145 \pm 10.5)$. The difference was significant $(p<0.05)$. The scores of diabetic groups were significantly lower than the control groups. These data are summarized in Table 4.

Table 4 - Values of the histological scores in the wounds of rats from respective groups at $10^{\text {th }}$ day of observation. (Measured using ImagePro 6.0 software).

\begin{tabular}{ll}
\hline Groups & Wound scores \\
\hline C/NS & $186 \pm 8.3^{\mathrm{a}}$ \\
$\mathrm{C} / \mathrm{ME}$ & $274 \pm 11.8^{\mathrm{a}, \mathrm{c}}$ \\
$\mathrm{DIAB} / \mathrm{NS}$ & $145 \pm 10.5^{\mathrm{a}, \mathrm{b}}$ \\
DIAB/ME & $198 \pm 13.7^{\mathrm{b}, \mathrm{c}}$ \\
\hline
\end{tabular}

C, control; ME, Moringa extract; DIAB, Diabetes; NS, normal saline. Measures followed of the same letter in the same column differ significantly ( $p<0.05$, Tukey test).

\section{Discussion}

The present experimental model of cicatrization of skin wounds in rats, performed after induction of diabetes by streptozotocin, was done with the purpose of analyzing the effects of a phytotherapeutical on healing. We studied the evolution of the lesion area over time and we found that the effect of the Moringa oleifera extract was positive in reducing the wound area up to the 10th day when compared to the controls, treated with normal saline. We have speculated that this favorable effect occurred for some reasons. Firstly, the reduction that occurred in glycemia of diabetic animals after treatment with Moringa oleifera extract. In fact, we had the initiative to treat the animals in two ways: the first, by oral extract (gavage) and the second by topical application in skin wounds. The systemic use should have contributed to the reduction of glycemia in the animals of groups 3 and 4 , with diabetes induced by streptozotocin. Consequently, improving the healing process. Topical use certainly had an additional effect on the wounds healing.

Macrophages are the main cells that influence the wound healing process. They are very active phagocytes that remove foreign bodies, bacteria and have direct granular tissue 
development. Then, fibroblasts appear deriving from perivascular cells of the injured tissues and endothelial cells migrate towards the wound increasing tissue permeability and collagen fiber production. The events of this phase are fibroblast proliferation, subsequent collagen synthesis and reduction in vascularization by a contraction process ${ }^{1}$. All these mechanisms must have been stimulated by the Moringa oleifera extract. In the present study, the histopathological examination quantitatively analyzed neovascularization, fibroblasts, macrophages and collagen fibers. We observed that in the groups of diabetic and nondiabetic animals, the systemic and topical treatment with the Moringa oleifera extract positively influenced the quantification of the histological scores. It is known that neovascular tissue and macrophages carry chemical mediators, such as cytokines, enzymes, oxygen and vitamins that are essential to establish high quality fibroblast for collagen synthesis and maturation ${ }^{12}$. Therefore, fibroblast proliferation and collagen production is a way to study the activity of drugs on healing ${ }^{13}$. Some models of specific inducible macrophage depletion, based on genetically modified mice, resulted in detrimental effect of pre-injury depletion of macrophages ${ }^{14-16}$. About macrophage depletion, mice depleted before injury and during the granulation tissue formation typically have shown a defect in reepithelialization, granulation tissue formation, angiogenesis, wound cytokine production and myofibroblast associated wound contraction ${ }^{14}$. Delayed wound healing is a major complication of diabetes, and if not treated, it can lead to delay healing and chronic wounds such as diabetic foot ulcers ${ }^{17}$. In contrast, in the present study we observed an increase in the macrophage and fibroblast population, which contributed to increasing the histological score in the animals treated with Moringa oleifera extract and to high percent wound contraction.

As an antidiabetic agent, the leaves, pods, and seeds of Moringa oleifera have been scientifically proven ${ }^{11,18}$. Most of the researchers have used alcoholic or hydroalcoholic extract of Moringa oleifera leave. Nervertheless, the recommendation is that the only aqueous extract is preferable. In the present study we used aqueous extract ${ }^{19}$. We did not evaluate or isolate the possible therapeutic components of Moringa oleifera leaves, since the literature has a great variety of studies that did it. Antidiabetic properties of Moringa oleifera may be due to the presence of gallic acid, rutin, other flavonoids and phenolic metabolites ${ }^{7}$.

\section{Conclusion}

Moringa oleifera extract positively influenced the healing of skin wounds in a diabetic rat model, after systemic and topical treatment.

\section{References}

1. Childs DR, Murthy AS. Overview of wound healing and management. Surg Clin North Am. 2017;97(1):189-207. doi: 10.1016/j. suc.2016.08.013.

2. Gurtner GC, WernerS, Barrandon Y, Longaker MT. Wound repair and regeneration. Nature. 2008;453(7193):314-21. doi: 10.1038/ nature07039.

3. Mori R, Shaw TJ and Martin P. Molecular mechanisms linking wound inflammation and fibrosis: knockdown of osteopontin leads to rapid repair and reduced scarring. J Exp Med. 2008;205(1):43-51. doi: 10.1084/ jem.20071412.

4. World Health Organization. Global report on diabetes. Geneva: World Health Organization; 2016.

5. Marella S, Tollamadugu NVKVP. Nanotechnological approaches for the development of herbal drugs in treatment of diabetes mellitus - a critical review. IET Nanobiotechnol. 2018;12(5):549-56. doi: 10.1049/iet-nbt.2017.0242.

6. Mahmood KT, Mugal T, Haq IU. Moringa oleifera: a natural gift-a review. J Pharmacol Sci Res. 2010;2(11):775-81.

7. Dawood H, Fathy A. Extract of Moringa 
oleifera leaves ameliorates streptozotocininduced Diabetes mellitus in adult rats. Acta Histochem. 2014;116(8) 844-54. doi: 10.1016/j.acthis.2014.02.002.

8. Une Hemant D, Pradip S, Patave Tarannum R. A study on the effects of Moringa oleifera lam. pod extract on alloxan induced diabetic rats. Asian J Plant Sci Res. 2014;4(1):36-41.

9. Muhammad AA, Arulselvan $P$, Cheah PS, Abas F, Fakurazi S. Evaluation of wound healing properties of bioactive aqueous fraction from Moringa oleifera Lam on experimentally induced diabetic animal model. Drug Des Devel Ther. 2016;10(12):1715-30. doi: 10.2147/DDDT. S96968.

10.Marrufo T, Nazzaro F, Mancini E, Fratianni F, Coppola R, De Martino L, Agostinho A B, De Feo V. Chemical composition and biological activity of the essential oil from leaves of Moringa oleifera Lam. cultivated in Mozambique. Molecules. 2013;18(9):10989-11000. doi: 10.3390/ molecules180910989.

11.Gupta R, Mathur M, Bajaj VK, Katariya P, Yadav S, Kamal R, Gupta RS. Evaluation of antidiabetic and antioxidant activity of Moringa oleifera in experimental diabetes. J. Diabetes 2012;4(2):164-71. doi: 10.1111/j.1753-0407.2011.00173.x.

12. Reinke JM, Sorg $H$. Wound repair and regeneration. Eur Surg Res. 2012;49(1):3543. doi: $10.1159 / 000339613$.

13. Brancato SK, Albina JE. Wound macrophages as key regulators of repair: origin, phenotype, and function. Am J Pathol. 2011;178(1):1925. doi: 10.1016/j.ajpath.2010.08.003.

14.Minutti CM, Knipper JA, Allen JE, Zaiss
DM. Tissue-specific contribution of macrophages to wound healing. Semin Cell Dev Biol. 201761(1):3-11. doi: 10.1016/j. semcdb.2016.08.006.

15. Mahdavian Delavary B, van der Veer WM, van Egmond $M$, Niessen FB, Beelen $R H$. Macrophages in skin injury and repair. mmunobiology. 2011;216(7):753-62. doi: 10.1016/j.imbio.2011.01.001.

16.Goren I, Allmann N, Yogev N, Schürmann $C$, Linke $A$, Holdener $M$, Waisman A,Pfeilschifter J, Frank S. A transgenic mouse model of inducible macrophage depletion: effects of diphtheria toxin-driven lysozyme $\mathrm{M}$-specific cell lineage ablation on wound inflammatory, angiogenic, and contractive processes. Am J Pathol. 2009;175(1):13247. doi: 10.2353/ajpath.2009.081002.

17.Alavi A, Sibbald RG, Mayer D, Goodman L, Botros M, Armstrong DG, Woo K, Boeni T, Ayello EA, Kirsner RS. Diabetic foot ulcers: Part I. Pathophysiology andprevention. J Am Acad Dermatol. 2014;70(1):1-18. doi: 10.1016/j.jaad.2013.06.055.

18.Al-Malki, A. L., and El Rabey, H. A. (2015). The antidiabetic effect of low doses of Moringa oleifera Lam. seeds on streptozotocin induced diabetes and diabetic nephropathy in male rats. Biomed Res Int. 2015:381040. doi: $10.1155 / 2015 / 381040$.

19.Vongsak B, Sithisarn P, Mangmool S, Thongpraditchote S, Wongkrajang $Y$, Gritsanapan W. Maximizing total phenolics, total flavonoids contents and antioxidant activity of Moringa oleifera leaf extract by the appropriate extraction method. Ind Crops Prod. 2013;44(1):566-71. doi: 10.1016/j.indcrop.2012.09.021.

\section{Correspondence:}

Aldo Cunha Medeiros

Avenida Nilo Peçanha, 620

59012-300 Natal-RN Brasil

cirurgex.ufrn@gmail.com

Received: May 09, 2018

Review: July 10, 2018

Accepted: Aug 13, 2018
Conflict of interest: none

Financial source: CNPq (Grant 4449083/2014-4)

${ }^{1}$ Research performed at Nucleus of Experimental Surgery, Department of Surgery, Universidade Federal do Rio Grande do Norte (UFRN), Natal-RN, Brazil. Part of PhD degree thesis, Postgraduate Program in Health Sciences. Tutor: Aldo Cunha Medeiros. 